\title{
Socially Responsible Financial Products as a Contribution of Financial Institutions to Sustainable Development
}

\author{
Paweł Dec ${ }^{1, *(D)}$ and Piotr Masiukiewicz ${ }^{2}$ \\ 1 Professor at Institute of Corporate Finance, SGH Warsaw School of Economics, 02-554 Warsaw, Poland \\ 2 Professor at Institute of Value Management, SGH Warsaw School of Economics, 02-554 Warsaw, Poland; \\ piotr.masiukiewicz@wp.pl \\ * Correspondence: paweldec@gmail.com
}

check for

updates

Citation: Dec, P.; Masiukiewicz, P.

Socially Responsible Financial

Products as a Contribution of

Financial Institutions to Sustainable Development. Sustainability 2021, 13, 3067. https://doi.org/10.3390/ su13063067

\section{Academic Editors:}

Madeleine Granvik and Walter Leal Filho

Received: 1 December 2020

Accepted: 8 March 2021

Published: 11 March 2021

Publisher's Note: MDPI stays neutral with regard to jurisdictional claims in published maps and institutional affiliations.

Copyright: (c) 2021 by the authors. Licensee MDPI, Basel, Switzerland. This article is an open access article distributed under the terms and conditions of the Creative Commons Attribution (CC BY) license (https:/ / creativecommons.org/licenses/by/ $4.0 /)$.

\begin{abstract}
The article concerns the responsibility of financial institutions, primarily banks, for sustainable development and pro-ecological activities. The aim of the presented study is to identify the scope of activities of financial institutions in the field of sustainable development. What roles could banks have in contributing to sustainable development by offering socially responsible financial products? The authors conducted both quantitative research on a random group of Polish managers and a Delphi study on a group of several dozen experts, former members of the government, and bank presidents. The main results of the research indicate a $78 \%$ support among Polish managers for the activities of enterprises in accordance with the principles of sustainable development. More than $60 \%$ of the experts surveyed said that offering socially responsible financial products by banks is a growing trend in the economy. Moreover, two-thirds of the study's participants think that such products are to be characterized by lower fees and margins than other standard financial products. Examples of the most frequently mentioned and expected products include those related to the development of green energy and eco-innovations or waste disposal. The results of the conducted research clearly indicate the need for financial institutions or banks to offer socially responsible financial products, which should become a part of their development strategies.
\end{abstract}

Keywords: socially responsible financial products; bank; ecology; financial market; sustainable development; corporate social responsibility; environment

\section{Introduction}

Corporate social responsibility (CSR) is currently associated with the sustainable development of enterprises and the circular economy. Social responsibility has its roots in business ethics, which places an emphasis on responsibility (ethical and legal) for the company's decisions that may have an adverse effect on various stakeholder groups. In Poland, it is estimated that managers of the largest Polish companies are aware of the concept of responsible business. The growing interest in the corporate responsibility is visible in the growing number of companies presenting their practices in various types of reports each year. However, there are no wider research and publications in socially responsible financial products-hence the attempt is to define and pre-analyze this problem in this article. The need for a new type of banking that is more responsible and ethical compared to the traditional one is identified. The main research question is the following: is there a need and space for financial institutions (mainly banks) to offer socially responsible financial products in the context of their potential contribution to sustainable development? The hypothesis of the article is as follows: financial institutions can contribute to sustainable development by offering socially responsible financial products. The methods used in this study include literature analysis, comparative analysis, computer interview method, Delphi method, as well as case studies. The article introduces some new approaches to the activities of financial institutions, mainly banks, in the field of responsible sustainable development. It is an area not strictly associated with the offer of traditional banking and 
financial products, but with each year its impact on the business and economy of many countries increases.

In the literature on the subject, the authors often indicate that corporate social responsibility is currently equated with the sustainable development of enterprises and the circular economy [1-3]. There are also various ways and models of CSR implementation in different countries, such as the Nordic model [4-7]. In some scientific publications, the authors also mention socially responsible investments [8-10]. Banks, as key players in the financial market, implemented CSR procedures long ago [11-13]. The activities of banks, especially in new areas (such as those related to sustainable development), are also exposed to additional risk $[14,15]$.

\section{Materials and Methods}

The authors' research consisted of two phases: the initial phase and the main phase. The initial, signaling phase of research was conducted in November 2019 on a group of 100 managers (random selection: presidents, board members, senior managers, financial directors, company owners) from Poland. The interviews were conducted in Poland by a renowned research company using the method of computer-assisted telephone interviewing. Most of the respondents declared themselves the owner/co-owner of the company $(58 \%)$. Senior managers constituted $14 \%$ of the studied group, and $14 \%$ were finance directors. A group of presidents and board members was represented by $9 \%$ of the respondents. The initial research phase allowed us to identify specific research questions that were later used in the second, key phase of research in the field of socially responsible financial products.

In the main research (conducted in the second half of 2020), the authors used the corrected Delphi method, which is a heuristic method-a questionnaire survey based on closed questions that require measurable (quantifiable) responses. The method is based on the opinions of experts who work independently of others. To create a majority group, extreme opinions are rejected. This method is sometimes used to predict the future and make decisions under the conditions of risk and uncertainty. The term "expert" is defined variously in the literature but for the purposes of the Delphi panel, it should be understood in the broadest sense, i.e., as the eminent representative of science and practice dealing with a given issue. The limiting factors in this method involve the selection of appropriate criteria for the selection of experts, obtaining a satisfactory number of questionnaires, and the independence as well as objectivity of judgments (assessments) formulated by the experts. The accuracy of survey questions and the adequacy of the wording used were obtained in the course of an initial (trial)—verification survey among several experts.

The survey questions were closed, but with the column "other" (in some cases), where the respondents could express themselves freely. The research survey sought answers to the four following problems related to the functioning of socially responsible financial products: forecasting the future, preferred financial products and their prices, as well as evaluation of legal regulations in the EU. Questionnaires were sent to 104 key experts (feedback rate was $59.6 \%$ ) in Poland. The sampling was deliberate, according to the criterion of experience in managing financial institutions during the period of scientific or professional work and combining work in business with work in science. The structure of the respondents is presented in Table 1.

Table 1. The structure of the main survey respondents.

\begin{tabular}{ccc}
\hline No. & Specification & Number of Sent Questionnaires \\
\hline & Surveys for practitioners (financial market) & 53 \\
1 & - including former presidents and vice presidents of banks and financial & 35 \\
institutions in Poland & 2 \\
\hline
\end{tabular}


Table 1. Cont.

\begin{tabular}{ccc}
\hline No. & Specification & Number of Sent Questionnaires \\
\hline & Surveys for academics & 51 \\
& - including former presidents and vice presidents of banks and financial \\
institutions in Poland & 10 \\
& - including former ministers and deputy ministers of the Polish government & 9 \\
& - including former presidents and vice presidents of banks and financial \\
institutions in Poland & 104 \\
& - including former ministers and deputy ministers of the Polish government & 45 \\
\hline
\end{tabular}

Source: own study.

Surveys were conducted online with the use of an individually prepared survey system, with the confidentiality of respondents' data. Sample research questionnaire and a list of key experts were at the disposal of the authors of the research.

\section{Results}

It was crucial for the authors of the study to find the opinions of managers from Poland on whether it is important to follow the principles of sustainable development in business activities. It often happens, after all, that seemingly generally accepted codes or standards are not followed at the level of individual entities. Less than half of the surveyed managers $(40 \%)$ in Poland confirmed the need to consider the principles of sustainable development in their business activities in every situation (Figure 1). However, this coefficient may indicate either a lack of education in this area or a certain opportunism of Polish managers regarding these rigid rules. This is confirmed by $38 \%$ of indications regarding the conditions in which such rules should be used in the companies (see Figure 1). Only 15\% of Polish managers are determined to selectively follow such rules, making it dependent on the current economic cycle. This shows a strong attachment of some managers to achieving the basic goal in the short term, which is profit, and only in the longer term to consider other factors, even those seemingly obvious and serving the general good of society. A small group of Polish managers (5\%) stated that their business activities did not comply with the principles of sustainable development. It is worth trying to reach this group and educate it on the positive aspects of sustainable development.

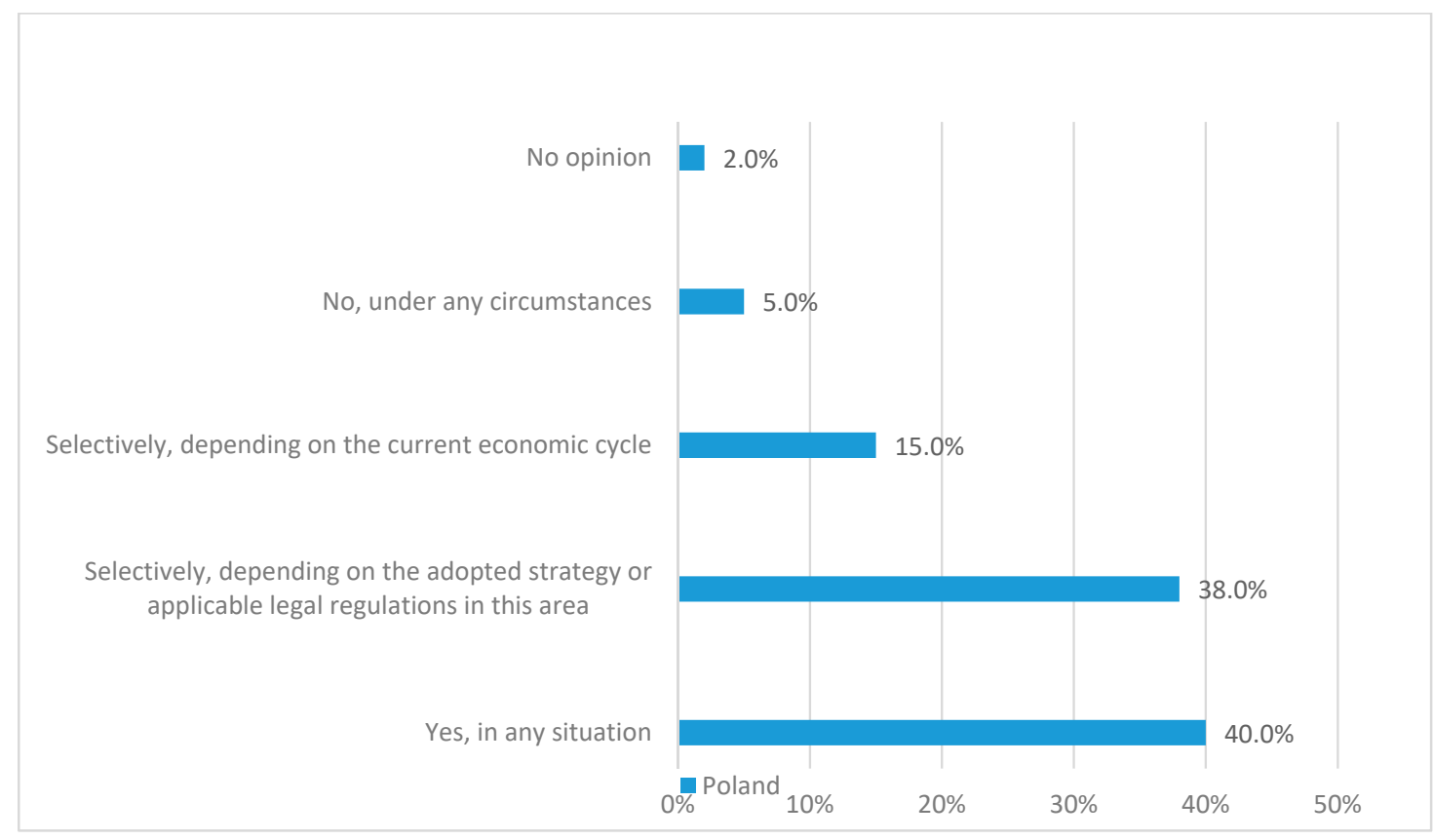

Figure 1. Activity of enterprises and the principles of sustainable development. Source: own study. 
Based on the unequivocal results of the first phase of the research, which showed that most companies and institutions follow the principles of sustainable development in their business activities, we were able to move to the main research phase. Four rounds of questions allowed us to obtain results described in the following part of the article.

Responses of the surveyed experts were characterized by a clear focus on specific categories of responses. When asked about the opinion on the offering of socially responsible financial products in the financial institutions, over $60 \%$ of the surveyed persons stated that it was a growing trend, and only about $19 \%$ considered it a temporary fashion (Table 2).

Table 2. Assessment of trends in offering socially responsible financial products.

\begin{tabular}{ccc}
\hline No. & Does Offering Socially Responsible Financial Products in Financial Institutions Mean: & $\%$ of Answers \\
\hline 1 & Growing trend & 61.3 \\
2 & Constant trend & 11.3 \\
3 & Fad & 19.3 \\
4 & Fading tendency & 1.6 \\
5 & No opinion & 6.5 \\
\hline
\end{tabular}

Source: own study.

It is important to point out that most experts (over 66\%) think that when offering socially responsible financial products one should operate on a lower margin and commission compared to other standard products (Table 3). On the other hand, one in four respondents was convinced that there should be no price differential among different categories of the products.

Table 3. Prices of socially responsible financial products.

\begin{tabular}{ccc}
\hline No. & Should a Socially Responsible Financial Product in a Bank (e.g., Preferential Ecological Loans): & $\%$ of Answers \\
\hline 1 & Have a lower margin and commission than standard products & 66.2 \\
2 & Have the same margin and commission as other products & 25.8 \\
3 & Have a higher margin and commission & 4.8 \\
4 & No opinion & 3.2 \\
\hline
\end{tabular}

Source: own study.

Considering the question-which socially responsible financial product, according to you, implements the principles of sustainable development to the greatest extent (with a significant limitation to a maximum of three answers), the most responses concerned loans for ecological innovations, loans for waste disposal and loans for green energy (Table 4).

Table 4. Financial products implementing the principles of sustainable development.

\begin{tabular}{ccc}
\hline No. & $\begin{array}{c}\text { Which Socially Responsible Financial Product, According to You, Implements the Principles of } \\
\text { Sustainable Development to the Greatest Extent (Select up to 3 Answers): }\end{array}$ & \% of Answers \\
\hline 1 & Loans for eco-innovations & 43.5 \\
2 & Credits for green energy & 62.9 \\
3 & Loans for clean air projects & 41.9 \\
4 & Loans for clean water projects & 33.9 \\
5 & Thermal insulation loans & 27.4 \\
6 & Loans for waste disposal & 43.5 \\
7 & Electric car loans & 8.1 \\
8 & Loan for the cultivation of organic food & 14.5 \\
9 & Credits for trading in used clothing, electronics, etc. (in the field of sharing economy) & 8.1 \\
10 & Other & 1.4 \\
11 & No opinion & 2.3 \\
\hline
\end{tabular}


In the descriptive round, the respondents also mentioned other green economy projects, i.e., investments in education and building trust to convince people that the actions taken make sense (e.g., nationwide standardization of the waste segregation process, standard collection of individual types of waste, information on what happens with a given type of garbage, what are the benefits), a restrictive act for conscious environmental pollution and littering the landscape is very important, and loans are needed for installations for greening wastelands. The need to finance public green infrastructure was also mentioned, i.e., environmentally friendly educational, cultural and sports institutions.

It is worth mentioning that the assessment of legal regulations in the EU concerning socially responsible financial products was very poor. As many as $40 \%$ of the respondents stated that the regulations require supplementation, and around $27 \%$ that they are insufficient (Table 5).

Table 5. Assessment of the European Union's legal regulations in the field of socially responsible financial products.

\begin{tabular}{|c|c|c|}
\hline No. & $\begin{array}{l}\text { Are the Legal Regulations Concerning Socially Responsible Financial Products in } \\
\text { the European Union: }\end{array}$ & $\%$ of Answers \\
\hline 1 & Sufficient & 11.3 \\
\hline 2 & They require additions and corrections & 40.3 \\
\hline 3 & They are insufficient & 27.4 \\
\hline 4 & No opinion & 21 \\
\hline
\end{tabular}

Source: own study.

The conducted research, both the initial and the main one, allowed, after consultation and discussion with the selected experts, to present the most important final conclusions and set the direction for further research.

\section{Discussion}

The concept of a socially responsible product is associated with the category of socially responsible banks. Benedikter [16] states that banks focus on community investment, supporting social, environmental, and ethical programs, and on creating financial opportunities for people in bad financial situations. When making financial decisions, they are guided not only by the rule of profit maximization, but they follow three principles: profitpeople-planet, which also means promoting human rights and protecting the environment. The implementation of these principles shows that "social" banks are interested not only in who they lend money to, but also for what purpose. Goyal and Joshi [17] and Maqbool and Zameer [18] indicate in their research that for socially responsible banks, the fact of lending for social purposes is more important than to just generate a profit. Research by Forcadell and Aracil [19] also showed that banks' efforts to build a reputation in the field of CSR brings significant benefits. Therefore, the development of this type of banking has been visible in recent years [20,21].

Pressure from stakeholders of financial institutions to maximize profit may be a significant obstacle in the development of socially responsible financial products. In the discussion on corporate social responsibility, the question arises of whether financial products can contribute to sustainable development (and are they socially responsible). The obtained study results confirm such a development, and banks are increasingly expected to offer socially responsible financial products. Our research even shows that such a product category could be offered on preferential terms. It is also possible that initiatives such as EMAS - an audit system for organizations in the field of environmental policywill be widely recognized and the circle of their recipients and direct participants will grow [22]. Indeed, the social responsibility of economic operators is partly about meeting environmental requirements for products $[23,24]$. However, the scope of corporate social responsibility reaches well beyond these requirements. On the other hand, the General Product Safety Directive aims to ensure the safety of all products present on the market in the European Economic Area. It applies to all products in the context of the provision of services and covers technical aspects; it is therefore rather not applicable to financial 
products [25]. We are aware of certain limitations in the development of socially responsible financial products, as their number cannot constantly grow due to their character and specific purpose, as well as a limited group of clients for such products. Development of this product category can be positively stimulated by the results of global research on people's attitudes in the broadly understood area of CSR. Nielsen, in its international study Doing Well by Doing Good [26], found that $55 \%$ of shoppers were willing to pay more for products and services from socially and environmentally responsible companies. Nielsen shows an increase in this trend by more than a dozen percent since 2011. Both the Deloitte [27] research and the Nielsen report [26] revealed that approximately $70 \%$ of respondents aged 18-49 would prefer to work in a company that positively impacts the environment and local community.

According to the previous research $[23,28]$ consumers are willing to pay more for socially responsible products. Results presented in this study suggest that socially responsible financial products need to be offered at lower, preferential margins. This shows a certain duality which is worth subjecting to future research. In the construction of a socially responsible insurance product, the dimension of customer relations is considered particularly important [29].

Hence, there are two types of responsibility of a financial company for a financial product: legal responsibility and social (moral) responsibility. Types of financial products according to the criterion of social responsibility are shown in Figure 2. Presence in the index of socially responsible companies, RESPECT Index (index of the Warsaw Stock Exchange) and in the sustainable development index, CEERIUS (CEE Responsible Investment Universe) confirms the highest CSR standards. It could also serve as a benchmark and direction for other markets. The fact that many banks implementing CSR programs are concentrated in GABV (Global Alliance for Banking on Values) is symptomatic. It is an independent association that uses finance to achieve sustainable development of its clients, communities and the environment. Organization includes innovative banking institutions that implement products and services to finance initiatives for the development of local communities and entrepreneurs taking into account social goals in their actions, promote sustainable development, are friendly to the natural environment, implement projects reducing poverty and improving the quality of life [1].

It is worth remembering that promoting clean energy sources and reducing emissions of harmful gases into the atmosphere are among the EU's priorities for 2021-2027. Many global and local financial institutions, including banks operating in Poland, prefer green investments [30]. Bank Ochrony Środowiska (BOŚ) has been offering preferential loans for many years in three segments: land, water, air, including loans for renewable energy sources. Another instrument is a loan for the thermomodernization and renovation projects with a premium from the Thermomodernization and Renovation Fund, which can be also used by individual customers (retail customers), companies and institutions.

BNP Paribas bank consciously limits its share in industries widely recognized as harmful and inconsistent with the principles of sustainable development. Bank Polskiej Spółdzielczości (BPS) plans to implement a loan for "eco" purposes within the next two months; it participates in works related to the implementation of the Clean Air program. ING Bank would traditionally finance the coal industry, but that is a thing of the past. Currently, the ING group belongs to a green banks group. It has not been financing coal fired power plants on a global scale since 2015 [30]. Furthermore, on the Polish market, ING Bank Ślaski has been offering a wide range of credit products dedicated to ecological solutions for three years now. The offer is directed to both private individuals and enterprises that want to contribute to reducing conventional energy consumption and increasing clean energy; in the case of the entire green offer, the bank resigned from charging a commission. The eco-loan for individual clients can be used to finance, e.g., solar collectors, photovoltaic cells, energy-saving household appliances, LED lighting, and others. People planning to buy their own apartment have access to an eco-mortgage loan for an energy-efficient house. A similar instrument, called an investment eco-loan, is also available 
to the boards of housing associations. In turn, entrepreneurs have at their disposal an eco-loan for companies, as well as an eco-leasing for hybrid and electric cars.

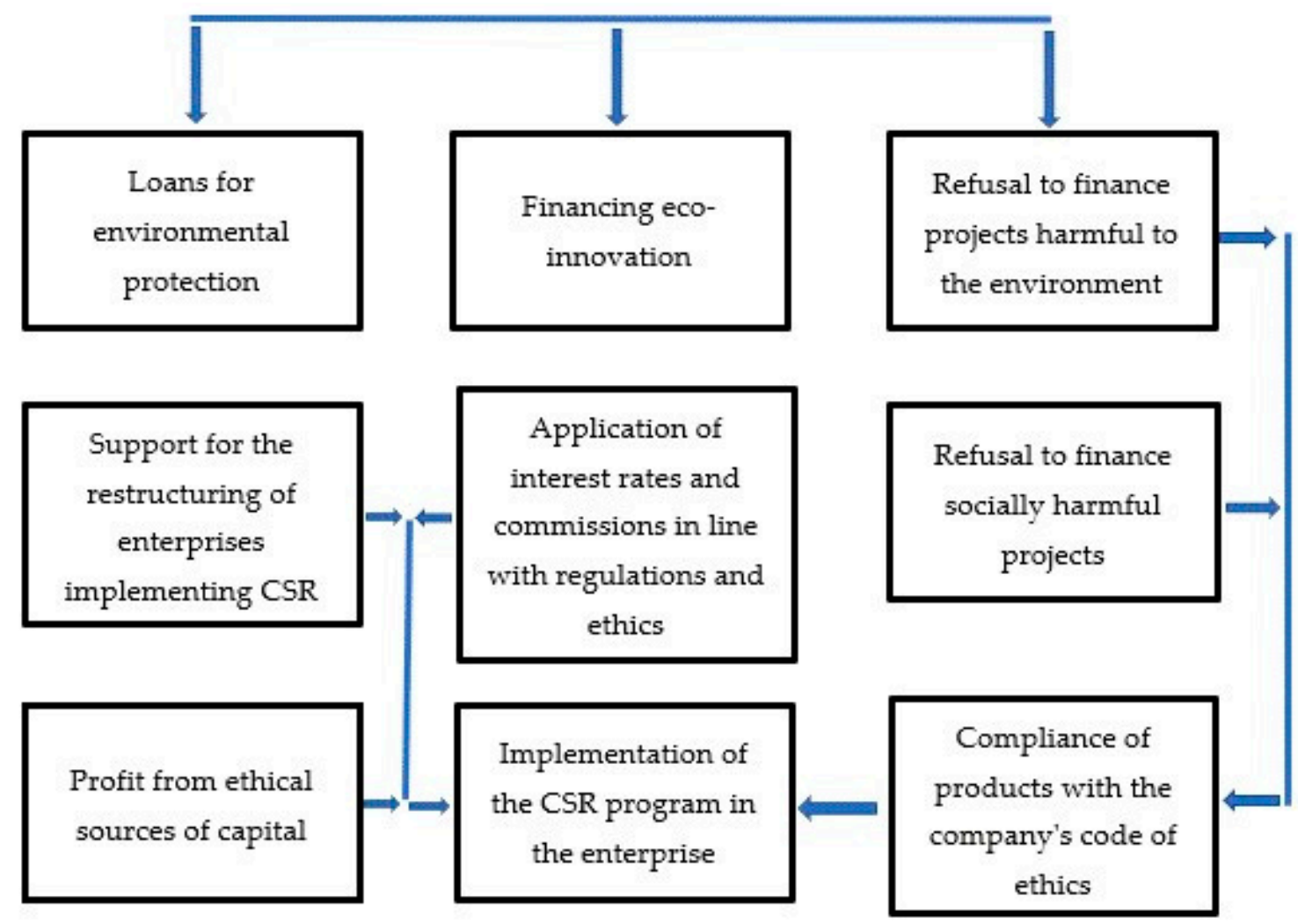

Figure 2. Socially responsible financial products. Source: own study.

This raises the question of why banks in Poland do not issue green bonds just like the banks in Great Britain. There, the leading share of the so-called green finances and the most important part of their market is created by the so-called green bonds (in 2019, over 100 different green bonds were listed on the London Stock Exchange (LSE), issued by representatives of 16 countries; these issues allowed to collect over USD 25.3 billion). The London Stock Exchange was the place where the world's first issue of certified green bonds and green covered bonds from China, India and the Middle East took place [31].

International initiatives in this area, such as the United Nations Environment Program Finance Initiative, under which The Principles for Responsible Banking were developed, are an additional stimulus for banks to further develop the society of responsible financial products [32]. Within this project, the Collective Commitment to Climate Action (CCCA) should be mentioned first, while it seems to be the most ambitious global banking sector initiative supporting the transition to a net zero economy by 2050. The key issue here seems to be the general acceptance, by as many banks, especially by those of a global reach, of these principles and, equally important, their implementation in practice, and not just the empty statements. It is also worth emphasizing that banks (signatories of the above initiative) are searching further for solutions and methods aimed at facilitating financing and supporting projects in green economy after the COVID-19 pandemic. The authors look at such initiatives somewhat critically, remembering the experiences of the subprime crisis of $2007 / 2008$, when most of the then-troubled large banks unscrupulously used public aid offered by governments of many countries. Hence, we have reasons to observe banks' activities in environmental or social responsibility areas with a certain distance, but we hope that these are long-term strategies and not just short-term plans focused on increasing their profitability. 
Coming to an end of the discussion, there is something a bit pessimistic about the future. Rifkin [33] argued that the evolution of the social economy will supersede the market economy "lateral peer to peer scaling of new collaborative enterprises (...) reduces the costs of production, marketing, and the supply of goods". He writes further: "the young generation (...) shares their houses, clothes, (...) shares transport. (...) This transformation is accompanied by a change in the human psyche-a leap towards the era of cooperation and awareness of the biosphere." These predictions turned out to be too optimistic, the global COVID-19 pandemic confined billions of people to their microenvironments. For years, nationalist parties in Europe have also been growing in strength. After all, they are not focused on openness and cooperation. Moreover, our research showed that the sharing economy is not in the group of the most preferred socially responsible products [34]. Furthermore, Rifkin's optimistic claim that "children everywhere are learning about the ecological footprint" is illegitimate; in general, environmental education is poor in many countries, including Poland, whose economy is based on coal energy, as well as India or Central Africa, where children do not learn at all or not to the extent they should, because they have to work for global corporations [35]. Of course, without extensive education of societies, there will be no sustainable development and socially responsible products, including financial ones-unfortunately, there is still a lack of financial resources and motivation for many governments.

\section{Conclusions}

In conclusion, this study provides insights into the specificity of socially responsible financial products. Global movements for sustainable development, including the circular economy, will cause consumers to pay more attention to socially responsible products, because they protect both the natural and social environment. This also applies to the financial products (services) sector-although with a slightly different approach due to its specificity. If even in Poland, the country of coal, some banks refuse to finance this industry, this is a breakthrough, although switching the country to other energy sources is an expensive and long-term process. Our research has shown that there is no other opinion of a majority of the studied companies than to implement the principles of sustainable development, and that offering socially responsible financial products in financial institutions, according to over $60 \%$ of experts, is a growing trend. However, worrying is the fact that, according to $40 \%$ of the respondents, regulations in the European Union in the field of socially responsible financial products require supplementation. Constant consumer education in such and other socially responsible products is constantly needed, in addition to a support program for them provided by the European Commission and national consumer protection offices. We are aware of the limitations of our research, which include the number of respondents surveyed, structured response forms, the lack of repetition of the research in subsequent years on different groups of experts. Therefore, we discussed the findings and their implications in the broadest context possible and we point to the need for the future research (possibly a similar study in other countries), as well.

Author Contributions: Concept and design, P.D. and P.M. Acquisition or interpretation of data, P.D. and P.M. Statistical analysis, P.D. and P.M. Drafting of the manuscript, P.D. Revision of the manuscript for important intellectual content, P.D. and P.M. Supervision, P.D. and P.M. Funding acquisition, P.D. Both authors have read and agreed to the published version of the manuscript.

Funding: This research was funded by the Collegium of Business Administration at Warsaw School of Economics, as part of funds for research and increasing scientific output. Paper was granted by The Baltic University Programme.

Institutional Review Board Statement: Not Applicable.

Informed Consent Statement: Not Applicable.

Data Availability Statement: The datasets used and/or analyzed during the current study are available from the corresponding author on reasonable request. 
Conflicts of Interest: The authors declare no conflict of interest.

\section{References}

1. Czechowska, I.D. Znaczenie społecznego aspektu bankowości dla funkcjonowania banków w niestabilnym otoczeniu. Studia Ekon. Uniw. Ekon. W Katowicach. Zesz. Nauk. Wydziałowe 2012, 105, 25-32.

2. Schroeder, P.; Anggraeni, K.; Weber, U. The relevance of circular economy practices to the sustainable development goals. J. Ind. Ecol. 2019, 23, 77-95. [CrossRef]

3. Schoden, F.; Siebert, A.; Keskin, A.; Herzig, K.; Straus, M.; Schwenzfeier-Hellkamp, E. Building a wind power plant from scrap and raising public awareness for renewable energy technology in a circular economy. Sustainability 2019, 12, 90. [CrossRef]

4. Gjølberg, M. Varieties of corporate social responsibility (CSR): CSR meets the "Nordic Model”. Regul. Gov. 2010, 4, 203-229. [CrossRef]

5. Fontana, E. Corporate social responsibility as stakeholder engagement: Firm-NGO collaboration in Sweden. Corp. Soc. Responsib. Environ. Manag. 2018, 25, 327-338. [CrossRef]

6. Isaksson, L.; Mitra, N. To legislate or not: That is the question-Comparing CSR. In International Dimensions of Sustainable Management; Springer: Cham, Switzerland, 2019; pp. 35-51. [CrossRef]

7. Mazboudi, M.; Sidani, Y.M.; Al Ariss, A. Harmonization of firm CSR policies across national contexts: Evidence from Brazil \& Sweden. Int. Bus. Rev. 2020, 29, 101711. [CrossRef]

8. Nilsson, J. Investment with a conscience: Examining the impact of pro-social attitudes and perceived financial performance on socially responsible investment behavior. J. Bus. Ethics 2008, 83, 307-325. [CrossRef]

9. Renneboog, L.; Ter Horst, J.; Zhang, C. Socially responsible investments: Institutional aspects, performance, and investor behavior. J. Bank. Financ. 2008, 32, 1723-1742. [CrossRef]

10. Escrig, O.E.; Muñoz, T.M.J.; Fernández, I.M.Á. Sustainable development and the financial system: Society's perceptions about socially responsible investing. Bus. Strategy Environ. 2013, 22, 410-428. [CrossRef]

11. Viganò, F.; Nicolai, D. CSR in the European banking sector: Evidence from a survey. In Corporate Social Responsibility in Europe: Rhetoric and Realities Corporate; Barth, R., Wolff, F., Eds.; Edward Elgar Publishing: Cheltenham, UK, 2009; pp. 95-108.

12. Pérez, A.; Del Bosque, I.R. The role of CSR in the corporate identity of banking service providers. J. Bus. Ethics 2012, 108, 145-166. [CrossRef]

13. Karkowska, R. Business model as a concept of sustainability in the banking sector. Sustainability 2020, 12, 111. [CrossRef]

14. Ma, T.; Jiang, M.; Yuan, X. Pay me later is not always positively associated with bank risk reduction-from the perspective of long-term compensation and black box effect. Sustainability 2019, 12, 35. [CrossRef]

15. Stephens, C.; Skinner, C. Banks for a better planet? The challenge of sustainable social and environmental development and the emerging response of the banking sector. Environ. Dev. 2013, 5, 175-179. [CrossRef]

16. Benedikter, R. European Answers to the Financial Crisis: Social Banking and Social Finance. The Europe Center. Available online: http:/ / spice.stanford.edu (accessed on 10 June 2020).

17. Goyal, K.A.; Joshi, V. A study of social and ethical issues in banking industry. Int. J. Econ. Res. 2011, 2, 49-57.

18. Maqbool, S.; Zameer, M.N. Corporate social responsibility and financial performance: An empirical analysis of Indian banks. Future Bus. J. 2018, 4, 84-93. [CrossRef]

19. Forcadell, F.J.; Aracil, E. European banks' reputation for corporate social responsibility. Corp. Soc. Responsib. Environ. Manag. 2017, 24, 1-14. [CrossRef]

20. Krause, K.; Battenfeld, D. Coming out of the niche? Social banking in Germany: An empirical analysis of consumer characteristics and market size. J. Bus. Ethics 2019, 155, 889-911. [CrossRef]

21. Gangi, F.; Mustilli, M.; Varrone, N. The impact of corporate social responsibility (CSR) knowledge on corporate financial performance: Evidence from the European banking industry. J. Knowl. Manag. 2019, 23, 110-134. [CrossRef]

22. Testa, F.; Rizzi, F.; Daddi, T.; Gusmerotti, N.M.; Frey, M.; Iraldo, F. EMAS and ISO 14001: The differences in effectively improving environmental performance. J. Clean. Prod. 2014, 68, 165-173. [CrossRef]

23. Tully, S.M.; Winer, R.S. The role of the beneficiary in willingness to pay for socially responsible products: A meta-analysis. J. Retail. 2014, 90, 255-274. [CrossRef]

24. Szyja, P. The role of the state in creating green economy. Oeconomia Copernic. 2016, 7, 207. [CrossRef]

25. The European Parliament and of the Council. Directive 2001/95/EC of the European Parliament and of the Council of 3 December 2001 on General Product Safety. Available online: https:/ / eur-lex.europa.eu/LexUriServ/LexUriServ.do?uri=OJ:L:2002:011:0004:0017: en:PDF (accessed on 20 October 2020).

26. Doing Well by Doing Good, Nielsen Global Survey of Corporate Social Responsibility, Q 1. 2014. Available online: https://www.nielsen. com/wp-content/uploads/sites/3/2019/04/global-corporate-social-responsibility-report-june-2014 (accessed on 17 April 2020).

27. Deloitte Volunteer IMPACT Survey. 2011. Available online: https://www2.deloitte.com/content/dam/Deloitte/us/Documents/ us-citizenship-2011-impact-survey-employee-engagement.pdf (accessed on 17 April 2020).

28. Becchetti, L.; Rosati, F.C. Global social preferences and the demand for socially responsible products: Empirical evidence from a pilot study on fair trade consumers. World Econ. 2007, 30, 807-836. [CrossRef]

29. Bożek, S. Społeczna odpowiedzialność biznesu a produkt ubezpieczeniowy społecznie odpowiedzialny. Pr. Nauk. Uniw. Ekon. We Wrocławiu 2017, 500, 9-20. [CrossRef] 
30. Mórawski, K.J. Zielona Oferta Polskich Banków. Available online: https:/ /www.alebank.pl (accessed on 23 July 2020 ).

31. The UK: A Global Hub for Green Finance. Available online: http://greenfinanceinitiative.org/wp-content/uploads/2016/10/ CLO-3-Green-finance-updated-2019-WEB.pdf (accessed on 20 September 2020).

32. UNEP Finance Initiative. The Principles for Responsible Banking. Available online: https://www.unepfi.org/publications/princ iples-for-responsible-banking/ (accessed on 6 January 2021).

33. Rifkin, J. The Zero Marginal Cost Society; Palgrave Macmillan: New York, NY, USA, 2014.

34. Dec, P.; Masiukiewicz, P. Sharing economy-Another approach to value creation. In International Business, Trade and Institutional Sustainability; Filho, W.L., Borges de Brito, P.R., Frankenberger, F., Eds.; Springer: Cham, Switzerland, 2019 ; pp. 797-811. [CrossRef]

35. Child Labour-UNICEF Report 2017. Available online: https://data.unicef.org/topic/child-protection/child-labour/ (accessed on 20 August 2020). 